\title{
頭頸部悪性腫瘍における重複癌症例の検討
}

\author{
瀧田正亮・谷口文章・林雨增 \\ 墨哲郎・大前政利・町谷卓男 \\ 川本知明 - 奥西泰子・作田正義
}

\section{Multiple malignant tumors in the head and neck cancer}

\author{
Masaaki TAKITA - Bunsho TANiguchi - Yue-tzeng LiN \\ Tetsuro Sumi - Masatoshi Ohmae - Takao Machiya \\ Tomoaki Kawamoto • Yasuko OKUnishi - Masayoshi Sakuda
}

\begin{abstract}
Twenty cases $(4.3 \%)$ of multiple primary malignant tumors, including 3 cases of oral multicentric carcinoma, were found among 463 patients with malignant tumor of head and neck region at the our department, from September, 1978 through August, 1989. Ten were male and ten were female. Their mean age was $67.7 \pm 11.5$ years with a range 34 to 82 years. Synchronous (within 1 year) tumor were 8 cases and metachronous were 12 . The average interval between the first and second tumors was 4.0 years with a range of from 6 months to 14 years.

There was a wide variety of other tumors distributed as follows: pharynx (3), bladder (2), and parotid region, thyroid, bronchus, breast, esophagus, stomach, uterine cervix, and skin, each. One of this group, forty percent ( $8 / 20$ cases, including oral multicentric carcinoma) were combined cancers of digestive system.
\end{abstract}

Three cases of radiation induced cancer were found.

Key words: multiple primary cancer (重複瘦), head and neck cancer (頭頸部癌)

緒言

重複悪性腫瘍は，平均寿命の延長や悪性腫瘍に対する 治療成績の向上に伴って近年增加する傾向にあり，口腔 癌を治療対象とするわれわれ口腔外科医の立場からも， 治療上看過できない問題として受け止められる。

今回われわれは最近の11年間に当科で経験された重複 悪性腫放20例を集計し，その奏態を報告すると共に，国 内の報告論文を中心に検討を加えたので報告する。

\section{対象症例および検討方法}

1978年 9 月〜1989年 8 月までの11年間に当科に受診し

大阪大学㳡学部口腔外科学第 2 諈座

（主任：作田正義教授）

The Second Department of Oral and Maxillofacial Surgery, Osaka University Faculty of Dentistry (Chief: Prof. Masayoshi Sakuda)

受付：平成 2 年 1 月 8 日
た悪性腫瘍患者は463名で，そのうち Warren and Gates $^{1)}$ の基準を満たし Moertel ${ }^{2)}$ のカテコリリてで整理・ 分類できる重複覀性腫瘍は, 口腔領域多発癌 3 例を含む 20 例 $(4.3 \%)$ にみられた。いずれる 組織型（細胞䛦を 含む）の確認できた症例に限り，臨床診断のみの症例は 対象から除いた。 また両腫場の発生時期の間隔について は, 確定診断（組織診断）の得られた時点を基準に算出 した。

\section{結果}

\section{1. 性別ならびに年齢}

男性10名，女性10名で，第 2 癌の発見時（確定診断 時）の年龄分布は34〜82嵗で平均 $67.7 \pm 11.5$ 歳であり， 当科初診時の平均年齢では65.6 11.4 歳であった（表 1).

\section{2. 組織型}

内訳は 1 次癌, 2 次癌を含め, 扁平上皮癌29例, 腺癌 7 例, 移行上皮癌 2 例の他骨肉腫および悪性黑色腫が各 1 例ずつであり, 組み合わせでは扁平上皮癌一扁平上皮 
表 1 当科における重複癌患者の内訳

\begin{tabular}{|c|c|c|c|c|c|}
\hline 症例 & 年此合 & 性 & 1 次癌（組緎型） & 発生間隔 & 2 次癌（組穖型） \\
\hline 1 & 67 & 우 & 子宮頸部（扁平上皮癌） & 4 年 9 か月 & 舌 (届平上皮癌)* \\
\hline 2 & 73 & $\hat{\delta}$ & 膀胱（移行上皮瘦） & 6 年 1 か月 & 下顎眱肉（扁平上皮癌） \\
\hline 3 & 57 & $\hat{\delta}$ & 上顎米肉（扁平上皮癌） & 6 か月 & 気管支（扁平上皮癌） \\
\hline 4 & 56 & $\hat{o}$ & 舌（扁平上皮瘦） & 1 年 6 加月 & 䏽胱（移行上皮癌） \\
\hline 5 & 52 & 우 & 舌（扁平上皮癌） & 7 か月 & 乳腺（腺癌） \\
\hline 6 & 70 & $\hat{0}$ & 喉頭（搹平上皮癌） & 9 年 2 か月 & 口底（居平上皮嵒） \\
\hline 7 & 61 & 우 & 臼後部（腺様胞癌） & 6 か月 & 甲状腺（滤胞状腺㾔） \\
\hline 8 & 78 & $\hat{\sigma}$ & 胃（腺瘦） & 1 年（未满） & 上顎㳡肉（㕃平上皮癌） \\
\hline 9 & 72 & 우 & 下顎菌肉（扁平上皮癌） & 1 年 8 か月 & 皮店（悪性黑色腫） \\
\hline 10 & 82 & 우 & 舌（扁平上皮癌） & 4 年 6 か月 & 食道（腺㾰） \\
\hline 11 & 52 & $\hat{\delta}$ & 舌（楅平上皮癌） & 5 年 1 か月 & 咽頭（冨平上皮癌） \\
\hline 12 & 68 & $\delta$ & 舌（扁平上皮癌） & 2 か月 & 咽頭 (扁平上皮癌)* \\
\hline 13 & 76 & 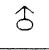 & 前立腺（腺癌） & 1 年 2 か月 & 下顎隣肉（扁平上皮癌） \\
\hline 14 & 66 & $\hat{\delta}$ & 口底（届平上皮癌） & 3 年 4 か月 & 耳下腺部（腺房細胞腫） \\
\hline 15 & 34 & 우 & 咽頭（腐平上皮癌） & 10年10か月 & 上顎骨（骨肉腫） \\
\hline 16 & 75 & 우 & 舌（扁平上皮癌） & 14年 2 か月 & 上顎幽肉（扁平上皮癌） \\
\hline 17 & 72 & 우 & 上顎洞（婳平上皮癌） & 13年 & 鼠腔（㕍平上皮瘦） \\
\hline 18 & 78 & 우 & 煩粘膜（疮烡癌） & $\gamma$ & 口蓋（唡平上皮癌） \\
\hline 19 & 79 & 우 & 舌（犹然瘦） & 11か月 & 口唇（槅平上皮瘦） \\
\hline 20 & 75 & $\hat{\delta}$ & 左下顎㳡肉（后平上皮癌） & 6 か月 & 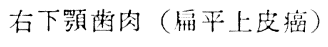 \\
\hline
\end{tabular}

* 初期癌

\#1 症例14〜17は1次瘦の治療に放射線療法か併用台九，乙の照射野内に 2 次瘦の発生を子たもの。

\#2症例18～19: 悾領域多発癌

澏10例（放射線誘発性の可能性の高い2 例を含吉), 扁平 上皮癌一腺癌 5 例, 扁平上皮癌一移行上皮癌 2 例, その 他, 扁平上皮癌一骨肉腫（放射楾誘発性と考兄られる）， 扁平上皮癌一要性黑色腫, 腺癌一腺癌が各 1 例ずつで, いずれも2 重複癌であった（表１）。

\section{3. 発生部位および臓器}

口腔領域側の腫瘳の発生部位については, 1 次癌では 辞が最も多く, 2 次癌では上・下顎雨肉に多く又られ, 当科に括ける単発性癌の部位別頻度 ${ }^{3,4)}$ に類似したもの であった（表 2 )。他臟器癌の発生部位については, 単 一蔵器に集中寸る傾向はなく，比較的多岐にわたってい る（表 3）が, 症例16，18２00の口腔領域内の重複例も 含め, 消化器系蔵器としてまとめると, 消化器系臟器お よび頭頙部領域内での重複は8 例 $(40 \%)$ といらことに なる。泌杘・生殖器系との重袥例は 4 例 $(20 \%)$ にみら れた。

\section{4. 発生間隔}

第 1 癌の診断時（確定診断時）から第 2 癌の診断時 （確定診断時）までの期間は, 関根 5 ) の基準に従うと1 年未満の同時性 8 例に対して 1 年以上の異時性は12例で
表 2 上顎洞掞よび口腔領域崲の部位別頻度

\begin{tabular}{|c|c|c|c|}
\hline 部位 & 1 次癌 & 2 次癌 & 言 \\
\hline 舌 & 6 & 1 & 7 \\
\hline 下顎粨肉 & 1 & 2 & 3 \\
\hline 上頡菤肉 & 1 & 2 & 3 \\
\hline 口底 & 1 & 1 & 2 \\
\hline 曰後部 & 1 & 0 & 1 \\
\hline 上顎骨 & 0 & 1 & 1 \\
\hline 上顎洞 & 1 & 0 & 1 \\
\hline 計 & 11 & 7 & 18 \\
\hline
\end{tabular}

口腔領域多発性瘦 3 例至除く。

あり，ての平均発生間隔は 4.0 年であった。発生間隔に より症例を分類し，午の予後について検討した（表 4). その結果, 現時点での同時性発生例の死亡率は50\%であ るのに対し，異時性発生例の死亡率は30\%であるが，発 生間隔10年以上の症例の死亡が目立つ。発生間隔10年以 上の症例とは，症例15，16，17であり，いずれも放射線 
表 3 他臓器瘦の部位

\begin{tabular}{|c|c|c|c|}
\hline 部位 & 1 次癌 & 2 次癌 & 計 \\
\hline 鼻腔 & 0 & 1 & 1 \\
\hline 咽頭 & 1 & 2 & 3 \\
\hline 㗋頭 & 1 & 0 & 1 \\
\hline 耳下腺部 & 0 & 1 & 1 \\
\hline 甲状腺 & 0 & 1 & 1 \\
\hline 気管支 & 0 & 1 & 1 \\
\hline 乳腺 & 0 & 1 & 1 \\
\hline 食道 & 0 & 1 & 1 \\
\hline 胃 & 1 & 0 & 1 \\
\hline 胯胱 & 1 & 1 & 2 \\
\hline 子宮 & 1 & 0 & 1 \\
\hline 前立腺 & 1 & 0 & 1 \\
\hline 皮店 & 0 & 1 & 1 \\
\hline 計 & 6 & 10 & 16 \\
\hline
\end{tabular}

表 4 発生間隔による分類およびその予後

\begin{tabular}{|c|c|c|c|}
\hline \multicolumn{2}{|c|}{ 発生間隔 } & \multicolumn{2}{|c|}{ 死亡例数/症例数 } \\
\hline 同時性 & 1 年末满 & $4 / 8(4 / 4)^{*}$ & \\
\hline \multirow{4}{*}{ 異時性 } & $1 \sim 3$ 年末満 & $0 / 3$ & \multirow{4}{*}{$4 / 12$} \\
\hline & $3 \sim 5$ 年未满 & $1 / 3(0 / 1)^{*}$ & \\
\hline & 5～10年未満 & $0 / 3$ & \\
\hline & 10以上 & $3 / 3(2 / 3)^{*}$ & \\
\hline \multicolumn{2}{|r|}{ 計 } & \multicolumn{2}{|l|}{$8 / 20$} \\
\hline
\end{tabular}

* 口腟癌に上る死亡例数/死亡例数
誘発性（それぞれ酒井らの放射線誘発癌の確信度分類6) のA-1群，B-1群，および B-1群に相当する）と考 えられるものであった。なお，症例 $14^{7)}$ は，放射線療法 を併用した口底癌症例で，1 次治療後照射野内に第 2 癌 の発生をみたものであり, 誘発性の可能性も示损される が，潜伏期間の点で確信度分類では判定できなかったこ とを付記する。

\section{5. 第 2 癌の発見状況について}

第 1 癌が口腔領域癌の症例で治療後, 他部位または他 臓器に第 2 癌が発生した症例の発見状況および第 2 癌の 対応をまとめた（表 5)。 そ結果，follow-up の中断し た症例および当科で対応した症例を除けば，口腔領域癌 の follow-up 中に当科で他蔵器の異常を発見し，い寸゙ れも該当する科への紹介により䛦断が確定された後，た だちに治療が開始されていることが示された。逆に他䐵 器 1 次癌症例の当科への来院経路については，1 次癌の 治療担当科より直接紹介を受けたものは, 症例13の1例 のみで，ほとんどの症例が近医歯科より紹介され来院し ていた（表6）.

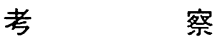

国内における主たる論文の中から頭頸部領域における 重複癌の発生件数についての臨床報告を抜粋し, まとめ てみた ${ }^{8 \sim 17)}$ (表 7)。耳奥科からの報告が主で，各施設 によって母集団の例数には多少の差がみられるが，1960 年代, 1970年代, 1980年代と, 口腔癌を含吉頭頸部領域 癌との重複癌の報告件数が增加してきていることが示さ れている。この傾向は同一施設での長期間にわたる多数

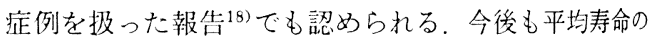

表 5 口悾領域 1 次癌症例の経過

\begin{tabular}{|c|c|c|c|c|c|c|c|}
\hline 症例 & $\begin{array}{l}\text { 口腔癌 } \\
\text { (部位) }\end{array}$ & 発生間隔 & 所 & 対 応 & 2 次癌 & 治 療 & 予後 \\
\hline 3 & 上顎萄肉 & 6 か月 & 胸部X線像異常 & 内科紹介 & 肺癌 & $\mathrm{CT}+\mathrm{RT}$ & 生 \\
\hline 4 & 舌 & 1 年 6 か月 & 尿沈査買常 & 泌尿科紹介 & 做胱癌 & $\mathrm{CT}$ & 生 \\
\hline 5 & 舌 & 7 か月 & 孚腺腫跟 & 外科紹介 & 乳癌 & OP & 死*1 \\
\hline 7 & 日後部 & 6 か月 & 甲状腺腫脹 & 外科紹介 & 甲状腺癌 & $\mathrm{OP}$ & 生 \\
\hline 9 & 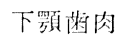 & 1 年 8 か月 & 頓部皮店照色腫瘤 & 皮墫科紹介 & 恶性黒色腫 & $\mathrm{OP}$ & 生 \\
\hline 10 & 舌 & 4 年 6 か月 & (flollow-up 中断) & & 食道痹 & $(-)$ & 死": \\
\hline 11 & 舌 & 5 年 1 か月 & 咽頭部腫腿 & 耳奥科紹介 & 咽頭瘦 & $\mathrm{RT}$ & 生 \\
\hline 12 & 舌 & 2 か月 & 咽頭部腫腿 & 放科紹介 & 咽頭㾔 & RT & 生 \\
\hline 14 & 口底 & 3 年 4 か月 & 耳下腺部腫瘤 & 当科 & 腺房細胞腫 & OP & 生 \\
\hline 16 & 舌 & 14 年 2 か月 & 碀肉腫脹 & 当科 & 上顎碀肉瘦 & $\mathrm{OP}+\mathrm{CT}$ & 死"1 \\
\hline$(17$ & 上顎洞 & 13年 & 奥出血 & 当科 & 奥腔癌 & CT & 死*2) \\
\hline
\end{tabular}

CT：化学療法 RT: 故的線療法

OP：手原療法

死因 $* 1$ 口腔癌 $* 2$ 他膈器癌 
表 6 他淢器 1 次癌症例の経過

\begin{tabular}{|c|c|c|c|c|c|c|}
\hline 症例 & 他䁍器癌 & 発生問隔 & 来院経路执よび所見 & 2 次癌 & 治 療 & 予 後 \\
\hline 1 & 子宮頸癌 & 4 年 9 か月 & \multirow{4}{*}{ （萊科より紹介来院） } & 舌癌 & $\mathrm{OP}$ & 生 \\
\hline 2 & 䐐胱癌 & 6 年 1 加月 & & 下䕱圈肉癌 & $\mathrm{RT}+\mathrm{OP}$ & 生 \\
\hline 6 & 喉頭痹 & 9 年 2 か月 & & 口厎癌 & $\mathrm{OP}$ & 生 \\
\hline 8 & 胃癌 & 1 年 (末満) & & 上顎棣肉癌 & $\mathrm{OP}$ & 死* \\
\hline 13 & 前立腺癌 & 1 年 2 か月 & $\begin{array}{l}\text { 泌尿科より } \\
\text { 骨シンチにて下顎に集䖽像 }\end{array}$ & 下顎幽肉癌 & $\mathrm{OP}$ & 生 \\
\hline 15 & 咽頭瘦 & 10年10か。月 & 耳奥科より+ & 上䫘骨肉腄 & $\mathrm{OP}+\mathrm{CT}$ & 死* \\
\hline
\end{tabular}

$\mathrm{CT}$ ：化学療法 RT：放射線療法 OP：手街療法

+: 放射線性骨剈炎炎の経過钼密中当科で発見

死因＊西膑領域癖

表 7 頍頜部頒域の重複癌の頻度

\begin{tabular}{|c|c|c|c|c|}
\hline 報 告 者 & 年 次 & 癌患者数 & 重複癌患者数 & $\%$ \\
\hline 中村8)（耳息科） & 1964年 & 374 & 6 & 1.60 \\
\hline 松村 ${ }^{93}$ (耳自科) & 1968年 & 420 & 6 & 1. 43 \\
\hline 住藤10) (耳鼻种) & 1971年 & 1,319 & 63 & 4.78 \\
\hline 犬山 ${ }^{11)}$ (耳科) & 1976年 & 1,093 & 23 & 2.10 \\
\hline 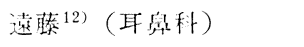 & 1977年 & 485 & 12 & 2. 47 \\
\hline 川本 ${ }^{133}$ (故的線科) & 1982年 & 2,802 & 132 & 4.71 \\
\hline 点多14)（耳曼科） & 1983年 & 947 & 66 & 6.97 \\
\hline 伊東 ${ }^{15)}$ (耳鼠科) & 1985年 & 658 & 28 & 4.26 \\
\hline 小野16)（ガンセンター） & 1987年 & 2,530 & 113 & 4. 47 \\
\hline 野口 ${ }^{17)}$ (口腔外科) & 1989年 & 412 & 26 & 6.31 \\
\hline
\end{tabular}

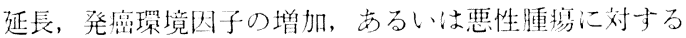
治療成績の向上なとに伴ってその発生頻度は增加してい くと考えられるが，重複癌の発生頻度を梌时与るには念 頭に置かなけれはなならない点がある。㹂米統計と病理解 剖統計とでは性質を異にするものであるし，現在のわが 国では診断根拠，検索対象（日集団），集計方法などに ついての取り扱い方が，各施設間において一定していな い,といら現状も踏まえなければならないとりわけ臨 林サイドから重要と思われる点は，治療後の推察期間と 第1癌の生存染である。たとえば長期間にわたって微察 すればするほ上当然重複癌の発生頻度は高くなるである うし，逆に第1癌の恶性度が高く生存摔が低くなれは， 患者の生存期間も短くなり他蔵器に第 2 癌が発生してい ても，てれが影性化与る前に死亡してしまう可能性があ る.

ちなみに1985年に行った当科集計 ${ }^{3)}$ にお忛る上䫇洞並 びに口腔領域扁平上皮癌148例の5 年生存率（1988 年 10 月末日を最終確認日として Kaplan--Meier 法により算 出）は59.3\%であるが，上・下顎迷肉癌における組織学 的悪性度評点から文た 5 年生存率では，低悪性群の 100

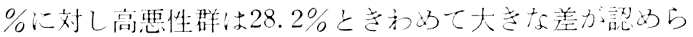

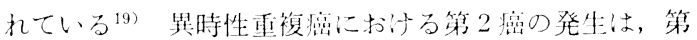

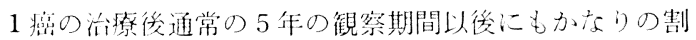
合で出現している11,13 15,20)こと, 放射線誘発癌（白血

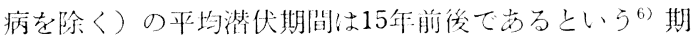
間を考虙すると, 上述の上5な予後不良の腫瘍群患者に おける第 2 癌発生の可能性も無視でさないものと考えら れる。したがって重複癌の発生件数の臨林報告について は，甘数を棈成している対象症例の内容（偈）によって

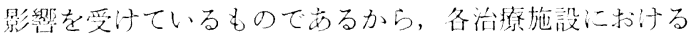
その年代ての治療状沉や，follow-up の状沉を踏ま坑 上での数值と解さなけ机はならない

重複癌の判定基準については, 古くからの Warren and Gates の基準1が，現在でもな㹡く用いられてい るが、これによれば 2 腫序間における組織型が同一であ れは，転移性か原発性かの判定が困難な場合が少なくな かった。しかしながら, 近年癌治療後の follow-up 態势 が整ってくるに従い，第 2 癌発生時の発見は比較的早期 (初期癌の状態) に行われることが多く，たとえば扁平 上皮癌とうしの組及合わせでも，既存の粘膜上皮や脈管 
との関係から原発性か転移性かの判断は谷易になるもの と思われる。今回の集計症例中雇平上皮滛どうしの組及 合わせは，症例 $1,3,6,11,12,16$ 200計10例で あるが，このうち症例 $1 ， 3 ， 6 ， 11 ， 20$ はい寸゙も生 検所見により 2 次癌が原発性扁平上皮癌であることが確

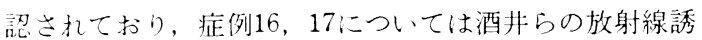
発性癌の確信度分類 ${ }^{6)}$ の B 群一 1 以上の基準を満足して いる。また症例18，19は，一方が亚型としての組及台わ せであるので，したがって，全例において転移性の否定 は容易にできたと思われる。

更複嵒に执いては, 腫瘍発生の時間的関係が重視さ れ，発生間隔により同時性と異時性とに分けられている が，現在のわが国ではその基準となる期間が，3 3 月以

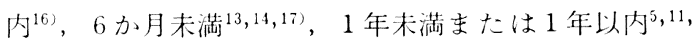
20)など報告者によりまちまちであり，また発生時期に対 する䛦断方法についても，一定の取り扱い規約がなく， 各施設によって異なっているのが現状である。この同時 性癌に対与る取り扱い方の違いは, IARC (International Agency for Research on Cancer ${ }^{21}$ や米国 NCI の SEER (Surveillance Epidemiology and End Result) ${ }^{22)}$ なとの多重複癌の登録に使用されているシステムに拈い てもみられる。現奉には発癌の時点でとらえることは困 難で，第 2 癌が 1 年以内に発現し証明された場合には同 時性, それ以上の場合には異時性として扱われることが 多い（5)とされている。今回の集計20例中発生間隔が 1 年 未满の同時性発生例として扱ったものは8例であるが, これはあくまでも確定診断（組織骖断）が得られた時期 をもとに集計したものである。症例 7 は, 発生間隔 6 か 月になっているが，当科初䧐時にはすでに甲状腺部にも 腫脹が文られ，ただちに本学医学部附属病院第 2 外科の 対骖を求めたところ, 甲状豚良性腫瘍と䧗休骖断され， 口腔倒腫痬の治療を先行させるといら力針が立てられた ために，結果的に甲状腺癌の確定骖断が遅れたものであ る. 㯺東的に false negaive を呈する場合には, 集計上 先行癌之続発癌が逆転する可能性がある。また，症例 8

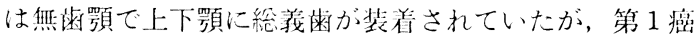
（胃癌）の治療後 IVH (intravenous hyperalimentation) により管理されており, 释い掑取が可能になった当科初 骖 6 か月前には，与でに $\mathrm{M}$ 部の料肉腫脹により義米の 不邂合を訴えていた。本症例も集計上は発生間隔 1 年末

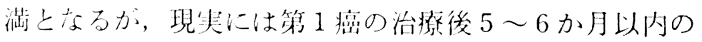
咕点て，第 2 癌はすでに顕住化していたものと思われ る。したがって発生間隔の算出については, 個々の症例 の受湸状沉によってかなり左有されるので，確定骖断時 (組織䧐断時)を第 2 癌の発生時期とするならは，第 1 癌 の䛦断後 1 年以内に骖断された症例については同時性, それ以上の症例を異時性として扱う方が無理がないよう に焽われる

口腔を含む頭頸部癌の他臓器癌との重複部位について
は，食道や胃との重複が多いとされている ${ }^{10,11,13 \sim 17)}$ か， 今回のわれわれの集計症例では, 特定の臟器に集中する 傾向はみられなかった。しかしながら、、腔領域多発癌 が3 例含まれているとはいえ，8例 $(40 \%)$ が消化器采贜 器との重複ということになり, また頭頸部癌どうしの重 複をみても 8 例 $(40 \%)$ を数えている。この面からは上 部消化器を满成する 口腔領域の癌に対しても field carcinogenesis $^{23}$,24)の認識を高めるとともに，放射線治療に 対する誘発性癌発生の可能性・危険性を念頭に膡いた follow-up が必要と思われる。なお，泌尿・生殖器系脸 器癌との重複は 4 例 (20\%) であり, 当該科が口腔外科 との関連の少ない診療科とはい方，綿密な連携が必要と 考えられる.

参考までに1984〜1988 年までの日本病理剖検輯報25) から，口唇を含む口腔癌との 2 重複癌発現部位の部位別 頻度を検討してみた（表 8 ）。消化器系葴器癌との重複 は合計 $62.6 \%$ を占めるが, 蔵器別では単発性癌の羅患率 が通常10位前後にランクされる食道癌 ${ }^{26,27)}$ が，口腔領域 癌との組及合わせでは第 1 位を占めていることは注目さ れる。

発生間隔による分類からみた子後については，1年末 满の同時性症例と10年以上の間隔を有する異時性症例に 死亡例が多くみられた。同時性の死亡例 4 例のらち 3 例 は高秢者の口腔領域多発性癌で, 適切な治療方針が立て られなかったことが，予後不良の背景因子と考えられ た。また，10年以上の間隔で発生した異時性症例の 3 例 は, いずれも放射線誘発性の可能性の高いものであり, 手術療法を行った 2 例についていえば，安全域の設定が 単発性のものに比べ困難で，その上処置法の制限，組織 の症痕化による手術施行上の困難さなどのため, 術後も 断端部周囲に遅発性に再発をきたし，制御できなかった ものである。放射楾誘発性癌の問題は，放射線治療を併 用する頻度の高い口腔領域癌に対しては, 生存率の向上 につれて，重要性を增寸課題の1つとなる。

先行癌の葴器別では, 口成空領域 1 次癌症例11例, 他䑏 器 1 次癌症例 6 例, および口腔領域多発癌症例 3 例とい 5 内訳であるが，この5ち前二者の第 2 癌の発見状況に ついては, 結果の( 5 )で取り上げた。第 1 癌が口腔領域 癌の症例すなわち口腔癌の治療後に, 第 2 癌が他脿器に 発生した症例については, 他缄器癌 (第2 癌) の早期発 見，早期治療に第 1 癌の治療科としての当科が，積極的 な役割を果たしていることが示されていた。一方他堿器 癌が第 1 癌であった症例については, 発生間隔の長い異 時性症例が多いといら点も考虑しなけれはならないが， 第 1 癌の治療科より直接紹介を受けたものは症例13の前 立腺癌の術後, ${ }^{67} \mathrm{Ga}$ 骨シンチによる検索で下䫇に異常 集秥像を認め, 当科に精相依頼をされた 1 例を除き, 他 はすべて近医歯科より紹介され米科しているのが現状て ある。このことは続発性癌の制御も重要となる重複癌症 
表 82 重複癌に打ける口腔癌との組み合わせ缄器

\begin{tabular}{|c|c|c|c|c|c|c|}
\hline & 1984 & 1985 & 1986 & 1987 & 1988 & 計 \\
\hline 食道 & $8(26.7)$ & $4(8.7)$ & $10(23.3)$ & $9(20.0)$ & $8(20.5)$ & $39(19.2)$ \\
\hline 胃 & $2(6.7)$ & $8(17.4)$ & $7(16.3)$ & $8(17.8)$ & $6(15.4)$ & $31(15.3)$ \\
\hline 䀒・旰内胆管 & $1(3.3)$ & $5(10.9)$ & $7(16.3)$ & $5(11.1)$ & $3(7.7)$ & $21(10.3)$ \\
\hline 虫垂・盲・結* ・直腸 & $2(6.7)$ & $7(15.2)$ & $1(2.3)$ & $5(11.1)$ & $3(7.7)$ & $18(8.9)$ \\
\hline 口腔（舌・蔯肉・他） & $4(13.3)$ & - & $2(4.7)$ & $4(8.9)$ & $1(2.6)$ & $11(5.4)$ \\
\hline 薪・ラ氏島 & - & - & $1(2.3)$ & $1(2.2)$ & $1(2.6)$ & $3(1.5)$ \\
\hline 下咽頭 & - & $2(4.3)$ & - & - & - & $2(1.0)$ \\
\hline 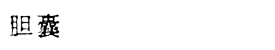 & - & $2(4.3)$ & - & - & - & $2(1.0)$ \\
\hline 肺・気管・気管支 & $4(13.3)$ & $8(17.4)$ & $4(9.3)$ & $6(13.3)$ & $7(17.9)$ & $29(14.3)$ \\
\hline 臭腔・上顎洞 & - & $1(2.2)$ & - & $1(2.2)$ & - & $2(1.0)$ \\
\hline 喉頭 & $1(3.3)$ & $1(2.2)$ & - & - & - & $2(1.0)$ \\
\hline 膀脱 & $2(6.7)$ & - & $1(2.3)$ & $2(4.4)$ & $2(5.1)$ & $7(3.4)$ \\
\hline 腎・他の泌㽷器 & - & - & - & - & $2(5.1)$ & $2(1.0)$ \\
\hline 子宮顒部 & $1(3.3)$ & $2(4.3)$ & - & $1(2.2)$ & - & $4(2.0)$ \\
\hline 乳腺 & - & - & $1(2.3)$ & - & $1(2.6)$ & $2(1.0)$ \\
\hline 卵樂 & - & - & - & - & $1(2.6)$ & $1(0.5)$ \\
\hline 前立腺 & $2(6.7)$ & $1(2.2)$ & $1(2.3)$ & $1(2.2)$ & $1(2.6)$ & $6(3.0)$ \\
\hline 甲状腺 & $2(6.7)$ & $2(4.3)$ & $1(2.3)$ & $1(2.2)$ & - & $6(3.0)$ \\
\hline リンハ・細網 & $1(3.3)$ & $1(2.2)$ & $5(11.6)$ & $1(2.2)$ & $1(2.6)$ & $9(4.4)$ \\
\hline 造血・具罚道 & - & - & $2(4.7)$ & - & $2(5.1)$ & $4(2.0)$ \\
\hline 骨 & - & $1(2.2)$ & - & - & - & $1(0.5)$ \\
\hline 脳 - 脳膜 & 一 & $1(2.2)$ & - & - & - & $1(0.5)$ \\
\hline 合計 & 30 & 46 & 43 & 45 & 39 & $203(100)$ \\
\hline
\end{tabular}

* S 字結腸含吉

（）は\%を示す

例では，先行癌の治療施設の果た寸责務は大きく，各施 設, 各科の連係を含めて, 䄸密な follow-up 態勢が確立 される方向で検討が行われる必要性を示すものである。

なお，大阪府下では，現在嵒患者登録制度が実施・整 備され ${ }^{27)}$ ，大阪府在住の嵒登録患者の追跡調查が可能て 岕る。重複癌の制御といら点からは1次癌治療科の果た 寸役割俚大きく，当科でも全例に癌登録索行い登録番号 を付与して，follow-up 態势を確立するとともに，5年 以上の長期の無癌生存例で患者の都合などにより来院で

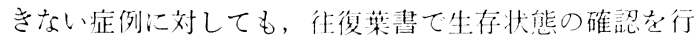
っている。

重複澏の発生要因については種々誐論されている多 が, 担癌状態や癌治療に伴万免疫能の低下は事実であ り, 体所的・遗伝的要因, 発癌環境なども重要な因子と して取り上活られるが, それらについて単発性癌と比校 することは, 冒頭で述べたごとく第 1 癌の生存期間や, follow-up 期間といら問題があるので，対象症例を铰密 に層別化して検討 29 しなければ，正確な結果は得られな いものと思水れる。放射線誘発癌についても，状況証拠
に基つく酒井らの確信度分類 ${ }^{6}$ に上り判定せざるを得な い現在ては，確定的な結論を下寺ことはてきないか，化 学療法に対与る重複癌発生の問題 ${ }^{30)}$ と电に, 今後の課 題として怡討されなければならない

\section{結語}

1. 最近の11年間に当科を受部した覀性腫瘍患者 463 名 に対して，口整領域多発癌 3 名を含导 20 名 $(4.3 \%)$ に 重複嵒症例が少ら!た。

2. 発生間隔 1 年未満の 同時性 8 例, 1 年以上の異時 性12例であり，現時点での死亡率法同時性の $50 \%$ (4/8 例）に対し，異時性の死亡率は $33 \%$ (4/12 例) であっ た。店扰，異時性症例の死亡例 4 例中 3 例は，放射線誘 発性滵の可能性の高いものであった。

3. 口腔領域癌に対与る重複癌蔵器は多岐に及几でい たが、口腔・咽頭を含旮消化器系臟器並びに頭項部領域 内での重複は，てれぞれ40\% (8/20例)を占めていた。 
本論支の整旨は平成元年10月の第34回日本口腔外科学 会総会 (郡山市)に打いて発表した。

\section{引用 文 献}

1) Warren, S. and Gates, O.: Multiple primary malignant tumors, a survey of the literature and a statistical study. Am J Cancer 16: 1358-1414 1932.

2) Moertel, C.G. Multiple primary malignant neoplasms Historical perspectives. Cancer 40: 1786-1792 1977.

3）流田正宽，町谷卓㞧，他：過去 5 年間に打ける

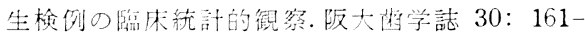
1681985.

4) 瀧田正竟, 林 雨增, 他：大阪大学楼学部附厘

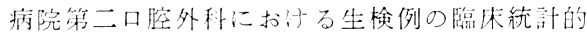
峴察一II（昭和58年10月～昭和63年 9 月）。阪 大棵学誌 34：232-239 1989.

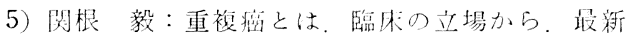
医学: 40：1580-1587 1985.

6) 酒井邦夫, 日向浩, 他：放射線治瘦後の発癌 に间一方全国調查成績。日医放会誌 41：24-32 1981.

7) 大来院光疹, 㴰田正完, 他：口在瘦の治療後に 発生した耳下腺部腺房細胞腫の1例。日口外誌 35：2240 (抄) 1989 .

8) 中村明正, 星谷徹, 他：重複癌6 例。耳喉 36: 945-947 1967.

9）松村袸二䬦，坂本守，他：最近経験した原発 性重䙉恶性腫疹の6 症例。耳奥 14：207-215 1968.

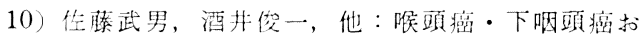
よび上䫇癌患者に2られた重䙓癌について。耳 17: $171-571971$.

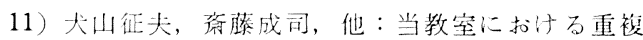
恶性腫序症例及び本邦報告例の統計的钼察。日 耳多 79: 189-202 1976 .

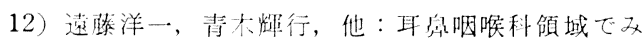


841-845 1977.

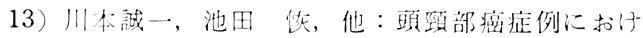
万重複狛一重衫部位・頻度など統計的考察—. 澢の猿术 28：1-7 1982.

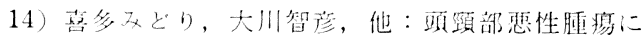
坋外万重被癌症例の检討。榴放 29:289-294
1983.

15）伊藤一則, 松崎 勉, 他：当教室過去 7 年間の 重複瘦について。顕頸部腫瘍 12: 1311985.

16）小野 勇：重複癌一その診断・治療頭頸部領 域と他茂器。最新医学 40: 1711-1715 1985.

17）野口誠, 平塚博義, 他：当科に扩重複癌 26例の臨床的検討。日瘦治 24：990-998 1989 .

18）大川智彦, 喜多みどり, 他 : Multiple primary malignant neoplasm of the head and neck. 日癌治 24：957-965 1989.

19) Takita, M., Taniguchi, B., et al.: Histologic evaluation of seventy cases of gingival carcinoma. 日瘦治 24 (抄): 1531989 .

20）加賀美芳和, 桜井智康, 他：重複癌症例の検 討。癌の臨床 26：896-899 1980 .

21) Maciennan, R., Muir, C., et al.: Cancer registration and its techniques. IARC Scientific Publications No. 21. IARC (International Agency for Research on Cancer), Lyon, p 54, 1978.

22) The code manual of the Surveillance Epidemiology and End Result (SEER) Program. National cancer Institute, Besthesda.

23) Slaughter, D.P., Southwick, H.Il., et al.: "Field cancerization" in oral stratified squamous epithelium. Cancer 6: 963-968 1953.

24) McGuirt, W.F., Matthews, B., et al: Multiple simultaneous tumors in patients with head and neck cancer. A prospective, sequential panendoscopic study. Cancer 50: 1195-1199 1982.

25）日本病理学会編：日本病理剖検輯報，第 26 輯 (1984) 〜第30輯 (1988).

26）藤本伊三郎，日本医学:会 /第80回日本医学会义 ンポジム指定発言一地域瘦登録の疫学的意 義。日医会雑誌 99：799-801 1988.

27) 大阪府環境保健部，大阪府医師会，大阪府立成 人病センタ一：大阪府に打けるが登録第 45 報一昭和 60 年のがんの罹患と医療一付。昭和 56 年羅㭧者の 5 年相対生存蜜。1988.

28) Boice, J.D., Storm, H.H., et al. : Introduction to the study of multiple primary cancers. Natl Cancer Inst Mongr 68: 3-9 1985.

29) 加藤充子, 富永祐民: 重複癌の疫学一癌登録上 り。最新医学 40：1588-1592 1985.

30) 棍谷鐶：重複癌とは。将来への展望。最新医 学: 40：1721-1724 1985. 